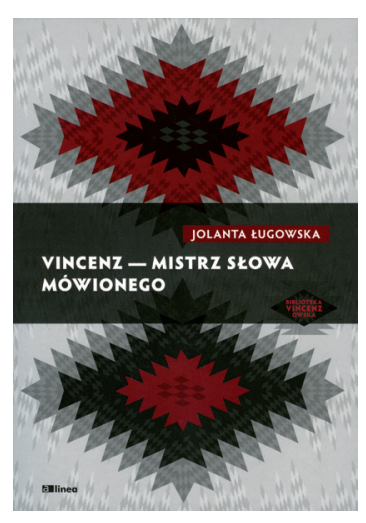

\title{
Homer Huculszczyzny jako homo loquens
}

DOI: $10.19195 / 2084-4107.10 .22$

[rec.:] Jolanta Ługowska, Vincenz - mistrz słowa mówionego, „Biblioteka Vincenzowska" 1, pod red. Jana A. Choroszego, Agencja Wydawnicza A-Linea, Wrocław 2015, ss. 170.

Homer of the Hutsuls as a homo loquens

Słowa-klucze: Karpaty, Huculszczyzna, Stanisław Vincenz, oralność

Keywords: Carpathians, Hutsuls, Stanisław Vincenz, orality

Książka Jolanty Ługowskiej Vincenz — mistrz słowa mówionego zainaugurowała nową serię wydawniczą „Biblioteka Vincenzowska”, poświęconą autorowi Na wysokiej potoninie. Jej redaktor, Jan A. Choroszy, od ponad trzech dekad niezmordowanie bada i propaguje twórczość mędrca z La Combe. Wystarczy wspomnieć przygotowanie do druku zapisków z lat 1938-1944 Outopos czy ostatnie prace związane z utworzeniem wortalu vincenz.pl. Tym samym Choroszy pragnie udowodnić, że w twórczości Vincenza drzemie wciąż ogromny potencjał zarówno czytelniczy, jak i badawczy, że trzeba ją propagować w kraju i poza jego granicami. A że nie są to działania efemeryczne, przekonuje informacja o dalszych planach wydawniczych, zapisana na tylnym skrzydełku książki — spodziewane są dwie kolejne pozycje: poświęcona tematom żydowskim praca 
Doroty Burdy-Fischer oraz tom zbiorowy traktujący o warsztacie pisarskim mistrza z Bystreca.

Czy jednak rzeczywiście, po niemal trzydziestoletnim procesie recepcji tej twórczości w Polsce, jest jeszcze miejsce na kolejne pozycje książkowe, poświęcone nowym jej aspektom? Przypomnijmy: Aleksander Madyda wnikliwie przeanalizował kwestię folkloru słownego w Połoninie, Piotr Nowaczyński pisał o Mądrości Vincenza, Mirosława Ołdakowska-Kuflowa spisała biografię pisarza i prześledziła jego stosunek do dziedzictwa kultury, a Michał Kaczmarek poświęcił tom swoich rozważań kwestii pamięci. Ale przecież na tym nie kończy się lista polskich vincenzologów, mamy bowiem dodatkowo cztery tomy zbiorowe tekstów badawczych i dziesiątki rozproszonych w czasopismach naukowych artykułów poświęconych rozlicznym aspektom tej twórczości.

Do grona wytrwałych badaczy twórczości Vincenza należy również Jolanta Ługowska, profesor Instytutu Filologii Polskiej Uniwersytetu Wrocławskiego. Jako filolog o zainteresowaniach folklorystycznych wydaje się osobą jak najbardziej predestynowaną do przyjrzenia się twórczości autora Połoniny z perspektywy oralnej, tym samym poszerzając perspektywę odczytywania tego cyklu.

Starannie, wręcz bezbłędnie edytorsko przygotowana książka, z wykorzystanym na okładce huculskim, geometrycznym motywem zdobniczym, zachęca do zagłębienia się w jej treść. Nim jednak to zrobimy, warto odnotować umieszczenie na końcu noty bibliograficznej, z której dowiadujemy się, że większość spośród siedmiu zasadniczych rozdziałów książki oparta jest na wcześniejszych, rozproszonych publikacjach. Książka nie jest więc odrębnie przygotowaną pracą badawczą, lecz raczej tomem artykułów pisanych już od pewnego czasu właśnie z bardzo konkretnej perspektywy badawczej - wspomnianej już oralności. Taka koncepcja wydawnicza zawsze nasuwa pytanie o spójność całości, nawet jeśli tekst został poprzedzony wstępem i zwieńczony słowem zakończenia. Do tej kwestii przyjdzie nam jeszcze powrócić.

Autorka odwołuje się do wielu tekstów Vincenza, ale analizuje głównie Potoninę i Rozmowy ze Stanisławem Vincenzem, notowane przez jego żonę Irenę Vincenzową. Przede wszystkim novum, jakie proponuje ta pozycja, to wgłębienie się w pisarstwo i biografię Vincenza w odwołaniu do klasyków badań nad kulturą oralną, zwłaszcza do Waltera Onga. Mamy tu jednak przywołane inne konteksty: Bachtinowską polifoniczność, dialogowość, którą w Połoninie badał Włodzimierz Próchnicki, ważną kwestią są rozważania genologiczne oraz koncepcja narratora, stąd częste odwołania do prac Krystyny Jakowskiej, znaczący kontekst stanowią też odwołania do przestrzeni - tu pojawia się klasyczna praca Yi-Fu Tuana czy artykuły Jacka Kolbuszewskiego. Oczywiście autorka przywołuje bardzo bogatą literaturę, zarówno etnograficzną czy antropologiczną, jak i literaturoznawczą, gdzie jej erudycja jest naprawdę imponująca.

Prześledźmy pokrótce zagadnienia, które przybliża Ługowska, stawiając kilkakrotnie tezę, że oralność jest podstawą warsztatu twórczego Homera Huculszczyzny (s. 11), a później rozszerzając ją także na sferę biograficzną, pisząc, że była 
ona też strategią komunikowania się Vincenza z otoczeniem (s. 60). Wspomina zatem o rytuale głośnego odczytywania tekstów przez autora Połoniny, i to nie tylko własnych, zarówno swej rodzinie, jak i przyjaciołom. Aby wskazać na korzenie tej postawy, Ługowska odwołuje się do wspomnień autora z dzieciństwa, w których dokonywała się jego inicjacja w kulturę żywego słowa - miał jej pozostać wierny do końca życia. W kilku miejscach możemy odnaleźć wyraźną sugestię, że wyjaśnienie fenomenu oralności u Vincenza, a szczególnie pojawienie się na kartach Połoniny scen biesiadowania, podczas którego kultywuje się sztukę żywego słowa, dysputy i opowiadania, można odnaleźć właśnie w jego biografii (s. 27 i dalej). Fascynacje Homerem i Platonem są wobec doświadczenia życiowego wtórne. Tu jako recenzentowi wypada mi wskazać pewne miejsca domagające się rozwinięcia. Otóż powołując się na stwierdzenie Onga, że „Bóg "przemawia« a nie pisze do istot ludzkich" (s. 21), autorka nie podejmuje, występującego w Połoninie, motywu „pisma światowego”, które komentował już Jacek Kolbuszewski. Natomiast gdy analizuje rozbudowane formy inquit (termin K. Jakowskiej określający językowe sygnały odnoszące się do mówiącego), nie wspomina o niezwykłym ich nagromadzeniu w Powojennych perypetiach Sokratesa.

Najbardziej chyba nowatorski, nigdzie jeszcze niepublikowany, jest rozdział poświęcony Rozmowom ze Stanisławem Vincnenzem, który wydobywa z cienia nietuzinkową postać jego drugiej żony Ireny, będącej nie tylko wierną przyjaciółką pisarza, ale również jego sekretarką i redaktorką, która wręcz „walczyła” (s. 66) o Połoninę, a nade wszystko ciekawą dyskutantką i świadomą wielkości swego męża kronikarką blisko dwudziestu lat wspólnego życia. W perspektywie tej wiedzy trudno sobie wyobrazić szczęśliwy finał wydania całości huculskiego cyklu bez niezwykłego poświecenia i ogromnej pracy jego żony. Kiedy więc autorka przytacza (w przypisie) znaną wypowiedź syna pisarza, Andrzeja, że Połonina była pierwotnie „tekstem mówionym”, dyktowanym żonie, która zapisywała go na maszynie, warto byłoby wgłębić się w to zagadnienie, i o ile to możliwe, sprawdzić, czy rzeczywiście ta praktyka pisarska odnosi się do całego cyklu, czy nie należy raczej do rodzinnego „mitu”, który należy poddać weryfikacji. Ciekawym też byłoby wykazać, co właściwie wynika z tej metody w samym tekście, jego potoczystości, brzmienia, melodii.

Osobny rozdział poświęca Ługowska zagadnieniu żywego słowa i kultury oralnej w tekście Połoniny, analizując szczegółowo konstrukcję serii opowieści, pojawiających się w Barwinkowym wianku, a poświęconych Żydowi Pinkasowi i panu Kołaszce. Zwraca przy tym uwagę, nie tylko tu zresztą, na same akty mowy, ich teatralizację i dramaturgię w przebiegu całego cyklu oraz na biesiadny charakter kultury żywego kontaktu, jaką reprezentowali Huculi Vincenza.

Kolejnym zagadnieniem jest fenomen „etykiety językowej”, jaką stosują w komunikacji „ludzie gór” Na wysokiej połoninie. Tutaj głównym bohaterem jest Foka i formy jego wypowiedzi, będące „strategiami grzeczności” (s. 91). Genezy tej specyficznej formy „celebrowania wzajemnego kontaktu” (s. 95) dopatruje się 
Ługowska - za treścią Połoniny — w doświadczeniu samotności pasterzy wśród gór. Tutaj warto uzupełnić, że inspiracją Vincenza była zapewne także, tłumaczona przez niego, rozprawa filozoficzna Rudolfa Marii Holzapfla Wszechideat, której pierwszy, otwierający rozdział, nosi właśnie tytuł Samotność.

W dalszym rozdziale autorka, opierając swój podział na koncepcjach Proppa, analizuje folklorystyczne formy gatunkowe Połoniny, szczególnie skupiając się na opowieści. Ważną konkluzją jest tutaj stwierdzenie, że

utrwalając na kartach Połoniny różnego rodzaju opowieści w wykonaniu huculskich protagonistów, Vincenz ukazuje zarazem sam mechanizm transmisji folklorystycznej, przyjmując niejako punkt widzenia użytkownika tradycji, traktującego wspólne duchowe dziedzictwo jako zespół możliwości czy zbiór segmentów, z jakich każdorazowo buduje własną opowieść. (s. 116)

Ta właśnie wewnętrzna perspektywa stanowi jeden z najważniejszych rysów całego cyklu powieściowego.

Wnikliwej analizie została poddana druga część cyklu, Zwada, w której autorka analizuje formy dyskursu. Gwoli uzupełnienia warto chyba dodać, o czym — jak mi się wydaje — nikt jeszcze nie wspomniał — a mianowicie, że Vincenz wykorzystał tu swoje doświadczenia z pobytu w sowieckim więzieniu. Kilka jego powieściowych postaci może mieć swoje pierwowzory wśród spotkanych w celi współwięźniów, a atmosfera na butynie jako żywo przypomina fragmenty wspomnień z Dialogów z Sowietami:

nadmieńmy, że z wypełnieniem się celi gościła ona lokatorów trzydziestu zamiast przepisowych sześciu. Spadły na nas różne klęski: ciasnota, brak łóżek, nawet sienników, złe powietrze, w dodatku okropny wikt. [...] Nabierając coraz większego animuszu młodzi komuniści zaczęli się wkrótce ścierać ze wszystkimi po kolei. Naprzód ze strażnikami więziennymi, a potem ze współwięźniami. Nauczyli się rychło rosyjskich wyzwisk i rozmiłowali się w nich. [...] Te walki kogutów trwały nieraz dość długo, a dyżurni sowieccy zbiegając się z korytarzy mieli z tego teatr i zaśmiewali się.

Warto pamiętać, że pomysł napisania Zwady narodził się już po lub może jeszcze w czasie doświadczeń wojennych Vincenza.

Ostatni rozdział Ługowska poświęca oswajaniu przestrzeni. Ta ciekawa refleksja, oparta na opisie budowy domostwa z Prawdy starowieku, najdalej odbiega od postulowanego oralizmu, niesie z sobą jednak ciekawe konkluzje, związane z rolą mitu w kształtowaniu huculskiej społeczności. Nawiązując do tez Piotra Nowaczyńskiego, autorka przychyla się do interpretacji Połoniny jako ukrytej polemiki ze światopoglądem racjonalnym. A więc można by dopowiedzieć również typem kultury opartej na piśmie. I tu właściwie książka mogłaby mieć swój finał. Zakończenie z kolei mogłoby służyć w tym przypadku scaleniu wniosków, 
Ługowska robi jednak coś innego, bardziej interesującego - opisuje stosunek Vincenzów, Ireny i Stanisława, do dawnych i nowych mediów: magnetofonu, filmu, telefonu czy listów. Zwłaszcza listy stanowią w biografii autora Połoniny fascynujący i niewiele zbadany jeszcze rozdział „swoistej rozmowy z adresatem" (s. 158). Na ich całościowe opracowanie i wydanie przyjdzie nam jeszcze zapewne długo poczekać.

Na postawione wcześniej pytanie: czy autorce udało się scalić wcześniej pisane artykuły w jedną rozprawę? — odpowiedź jest twierdząca. Ale też dodać należy, że nie jest to typowa synteza, to raczej zbiór studiów sumujących dociekania utrzymane w owej perspektywie badawczej, którą autorka zajmuje się już ponad dwie dekady. Czytelnikowi nieznającemu wcześniej prac Ługowskiej z tego zakresu lektura ta odsłani ważną perspektywę odczytania dzieła Vincenza. Jako książka naukowa zajmie ważne miejsce na mapie nie dość eksploatowanych dotychczas w piśmiennictwie polskim kierunkach badawczych, łączących perspektywę folklorystyczną i literaturoznawczą. I zapewne sięgną po nią nie tylko vincenzolodzy, lecz także ci, którzy będą podążać w badaniach literaturoznawczych tropem oralności.

Jakub Żmidziński 